
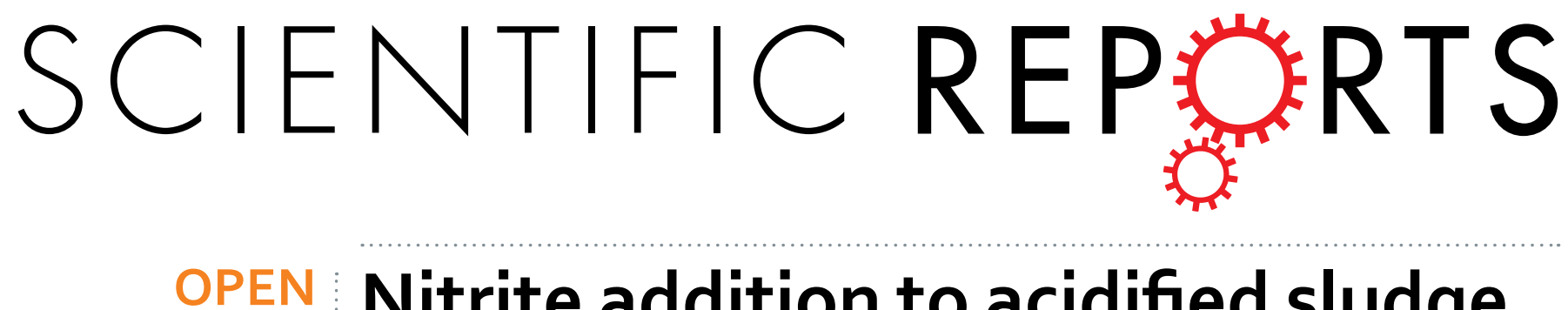

\title{
Nitrite addition to acidified sludge significantly improves digestibility, toxic metal removal, dewaterability \\ and pathogen reduction
}

Received: 13 April 2016

Accepted: 29 November 2016

Published: 22 December 2016

\author{
Fangzhou Du ${ }^{1}$, Jürg Keller ${ }^{1}$, Zhiguo Yuan ${ }^{1}$, Damien J. Batstone ${ }^{1}$, Stefano Freguia ${ }^{1}$ \& \\ Ilje Pikaar ${ }^{1,2}$
}

Sludge management is a major issue for water utilities globally. Poor digestibility and dewaterability are the main factors determining the cost for sludge management, whereas pathogen and toxic metal concentrations limit beneficial reuse. In this study, the effects of low level nitrite addition to acidified sludge to simultaneously enhance digestibility, toxic metal removal, dewaterability and pathogen reduction were investigated. Waste activated sludge (WAS) from a full-scale waste water treatment plant was treated at $\mathrm{pH} 2$ with $10 \mathrm{mg} \mathrm{NO}_{2}{ }^{-} \mathrm{N} / \mathrm{L}$ for $5 \mathrm{~h}$. Biochemical methane potential tests showed an increase in the methane production of $28 \%$, corresponding to an improvement from $247 \pm 8 \mathrm{LCH}_{4} / \mathrm{kg} \mathrm{VS}$ to $317 \pm 1 \mathrm{~L} \mathrm{CH}_{4} / \mathrm{kg} \mathrm{VS}$. The enhanced removal of toxic metals further increased the methane production by another $18 \%$ to $360 \pm 6 \mathrm{LCH}_{4} / \mathrm{kg} \mathrm{VS}$ (a total increase of $46 \%$ ). The solids content of dewatered sludge increased from $14.6 \pm 1.4 \%$ in the control to $18.2 \pm 0.8 \%$. A 4-log reduction for both total coliforms and $E$. coli was achieved. Overall, this study highlights the potential of acidification with low level nitrite addition as an effective and simple method achieving multiple improvements in terms of sludge management.

Large amounts of waste activated sludge (WAS) are generated by wastewater treatment plants (WWTPs) worldwide ${ }^{1,2}$. The management of this sludge is a major issue for water utilities and comprises a significant fraction of the operational costs of WWTPs ${ }^{3}$. The main factors incurring these high operational costs are mainly related to the poor digestibility and dewaterability of WAS, whereas the presence of pathogens and toxic metals limits beneficial reuse. It also represents an environmental burden, especially when incineration or landfill is needed ${ }^{4}$

Anaerobic digestion (AD) is a commonly used method for sludge stabilisation and energy recovery ${ }^{5}$. The relatively poor digestibility of WAS is a key process limitation, resulting in low biogas yields and long retention times ${ }^{6,7}$. Therefore, many studies aimed to enhance the digestibility of WAS using a variety of pre-treatment methods including biological, thermal, mechanical and chemical processes ${ }^{5}$. Although these methods have demonstrated enhancement of biogas production, the majority of these methods are relatively expensive or energy-intensive processes which have limited their widespread application. Therefore, there is a general interest and demand for more cost-effective and less energy-intensive treatment methods.

In addition to energy recovery, sludge can also be beneficially used as soil amendment or fertilizer ${ }^{8,9}$. However, the presence of toxic metals such as $\mathrm{Cu}$ and $\mathrm{Zn}$ limits the capacity of available land to receive sludge, particularly for repeated land applications. Consequently, the availability of arable land is becoming a limiting factor. Sludge with elevated toxic metal concentrations normally requires disposal/reuse in remote areas ${ }^{10}$, incurring higher transport costs. The disposal and transport costs are also strongly affected by the poor dewaterability of sewage sludge ${ }^{11}$.

It was reported that the treatment by free nitrous acid (FNA) significantly enhanced both anaerobic and aerobic digestion ${ }^{12,13}$ of WAS at an FNA concentration of only $2 \mathrm{mg}$ FNA-N/L (achieved by dosing up to $1500 \mathrm{mg}$ $\mathrm{NaNO}_{2} / \mathrm{L}$ at $\mathrm{pH}$ 5.5). Moreover, considering FNA was reported for its ability of cellular destruction and the strong biocidal effect ${ }^{14}$, FNA treatment may thus be effective in reducing pathogen concentrations in WAS. The latter is

${ }^{1}$ The University of Queensland, Advanced Water Management Centre (AWMC), QLD 4072, Australia. ${ }^{2}$ The University of Queensland, The School of Civil Engineering, QLD 4072, Australia. Correspondence and requests for materials should be addressed to I.P. (email: i.pikaar@ uq.edu.au) 


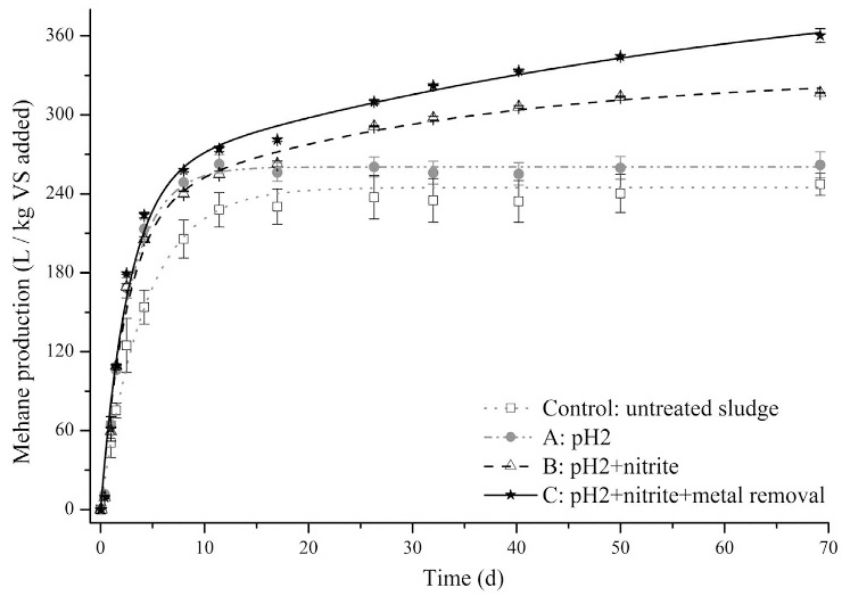

Figure 1. Cumulative methane production from WAS exposed to different pre-treatment. Dots represent the experimental data and lines represent the model fitting. Control and treatment (A) were fitted using firstorder one-substrate model, Treatment $(\mathbf{B}, \mathbf{C})$ were fitted using first-order two-substrate model. Error bars show standard deviation from triplicate tests.

required as a stabilisation process before land application ${ }^{15}$. Very recently, it was discovered that sludge acidification to $\mathrm{pH} 2$ combined with the addition of only $10 \mathrm{mg} \mathrm{NO}_{2}{ }^{-}-\mathrm{N} / \mathrm{L}$ strongly enhances toxic metal removal by solubilising organically bound metals ${ }^{16}$. It was assumed that the latter was caused by the disruption of extracellular polymeric substances (EPS) caused by FNA treatment. This hypothesis is supported by a very recent study which showed that FNA directly affects EPS by specifically targeting protein-like substances and hence breaking down the macromolecules within the EPS matrix into smaller molecules ${ }^{17}$. Toxic metals, including $\mathrm{Cu}$ and $\mathrm{Zn}$, are also known for their inhibitory effect on the AD process ${ }^{18,19}$. The enhanced removal of toxic metals may thus further improve the AD of WAS. It is known that EPS plays an important role in the dewaterability of sludge ${ }^{20}$, and as such the disruption of EPS by FNA may also affect the dewaterability of WAS.

Considering the above-mentioned recent studies outlining the versatile characteristics of FNA, we hypothesize that by the addition of low levels of nitrite to acidified WAS, it would be possible to simultaneously achieve considerable improvements in digestibility, toxic metal removal, dewaterability and pathogen reduction in one simple treatment step. The possibility of achieving multiple benefits in sludge management using one simple treatment method would make the proposed method attractive for practical application. This study therefore aims to investigate the effects of sludge acidification with the addition of small amounts of nitrite on the methane production from anaerobic digestion, dewaterability and pathogen reduction. In addition, this study also aims to determine the effect of enhanced toxic metal removal on the sludge digestibility. Model based analysis was adopted to estimate the methane production during continuous anaerobic digestion at a hydraulic retention time of 20 days.

\section{Results and Discussion}

Effect of acid and nitrite addition on sludge digestibility. The cumulative methane production from the anaerobic digestion of WAS exposed different treatments is shown in Fig. 1. At day 69 of BMP tests, the acidification treatment at $\mathrm{pH} 2$ (treatment A) only resulted in a minor increase in methane production of $5.9 \%$. On the other hand, the treatment at $\mathrm{pH} 2$ with nitrite addition (treatment $\mathrm{B}$ ) resulted in an increase in the methane production of $28.0 \%$. A further enhancement was observed for treatment $\mathrm{C} \mathrm{(pH} 2$ with nitrite addition and toxic metal removal), achieving an increase in methane production of $45.7 \%$. The results obtained here clearly show the effect of nitrite addition under acidic conditions (i.e. $\mathrm{pH}=2$ ) as well as the importance of toxic metal removal on the methane production.

The hydrolysis rate coefficient $(k)$ and biochemical methane potential $\left(B_{0}\right)$ were estimated using both first-order one-substrate model and two-substrate model. The one-substrate model gave satisfactory fit to the experimental data of control and treatment $\mathrm{A}(\mathrm{pH} 2)$. There was insufficient evidence $(p>0.05)$ to support a two-substrate model for control and treatment A (i.e. pH 2). However, nitrite addition (treatments B and C) had strong evidence $(p<0.05)$ of a two-substrate system with fits shown in Fig. 1 . The $k$ of treatment A was estimated to be $0.37 \pm 0.05 \mathrm{~d}^{-1}$, higher than the estimated $k$ of the control group with a value of $0.26 \pm 0.02 \mathrm{~d}^{-1}$ (Table 1 ). The $k_{\text {rapid }}$ of treatments B and C were estimated to be around $0.4 \mathrm{~d}^{-1}$.

In practice, mesophilic $\mathrm{AD}$ is more likely to be adopted in continuous mode with a typical HRT of about 20 days ${ }^{5}$. Therefore, a continuous reactor model with the obtained $k$ and $B_{0}$ was adopted to estimate the cumulative methane production for a continuous anaerobic digester operating at a hydraulic retention time (HRT) of 20 days (Table 1). By conducting two-tailed $t$-tests, it was found that the difference in methane production from each treatment (control, A, B and C) was significant $(p<0.01)$ to all the other treatments.

The $B_{0}$ values for all the treatments are presented in Fig. 2. As discussed above, treatments $B$ and $C$ were fitted with a two-substrate system. So the values of $B_{0}$ for treatment $\mathrm{B}$ and $\mathrm{C}$ were composed of $B_{0, \text { rapid }}$ and $B_{0, \text { slow. }}$. The error in the two substrate model was based on the error in methane yields for rapid and slow substrates, with hydrolysis coefficients fixed to their optima. The $B_{0 \text {, rapid }}$ of treatment $\mathrm{B}$ and $\mathrm{C}$ reached comparable values to the 


\begin{tabular}{|c|c|c|c|c|}
\hline Sludge treatment groups & $\begin{array}{l}\text { SCOD } \\
(\mathrm{mg} / \mathrm{L})^{\mathrm{a}}\end{array}$ & $\begin{array}{l}\text { VS destruction after } \\
69 \mathrm{~d} \text { of BMP }\end{array}$ & $\begin{array}{l}\text { Hydrolysis rate coefficient } \\
\left(k \text { or } k_{\text {rapid }}, \mathrm{d}^{-1}\right)\end{array}$ & $\begin{array}{c}\text { Estimated } \mathrm{CH}_{4} \text { production from } \\
\text { continuous } \mathrm{AD} \text { with } 20 \mathrm{~d} \mathrm{HRT}^{\mathrm{d}}(\mathrm{L} / \mathrm{kg} \mathrm{VS})\end{array}$ \\
\hline Control & $842 \pm 100$ & $42 \pm 1 \%$ & $0.26 \pm 0.02^{\mathrm{b}}$ & $200 \pm 6$ \\
\hline A: $\mathrm{pH} 2$ & $1950 \pm 33$ & $44 \pm 2 \%$ & $0.37 \pm 0.05^{\mathrm{b}}$ & $230 \pm 8$ \\
\hline B: $\mathrm{pH} 2+$ nitrite & $1749 \pm 17$ & $53 \pm 0 \%$ & $0.41 \pm 0.07^{\mathrm{c}}$ & $247 \pm 16$ \\
\hline C: $\mathrm{pH} 2$ + nitrite + metal removal & & $61 \pm 1 \%$ & $0.37 \pm 0.06^{\mathrm{c}}$ & $267 \pm 20$ \\
\hline
\end{tabular}

Table 1. Sludge solubilisation after different treatment, VS destruction and estimated hydrolysis rate coefficient $(\boldsymbol{k})$ for BMP tests. ${ }^{a}$ Error estimates are standard deviation from triplicate tests. ${ }^{b}$ Estimated from one-substrate model with $95 \%$ confidence interval based on a two-tailed t-test in parameter standard error. ${ }^{\mathrm{c}}$ Estimated from two-substrate model with $95 \%$ confidence interval based on a two-tailed t-test in parameter standard error. ${ }^{\text {E}}$ Estimated according to Batstone ${ }^{28}$ with $95 \%$ confidence interval based on a two-tailed t-test in parameter standard error.

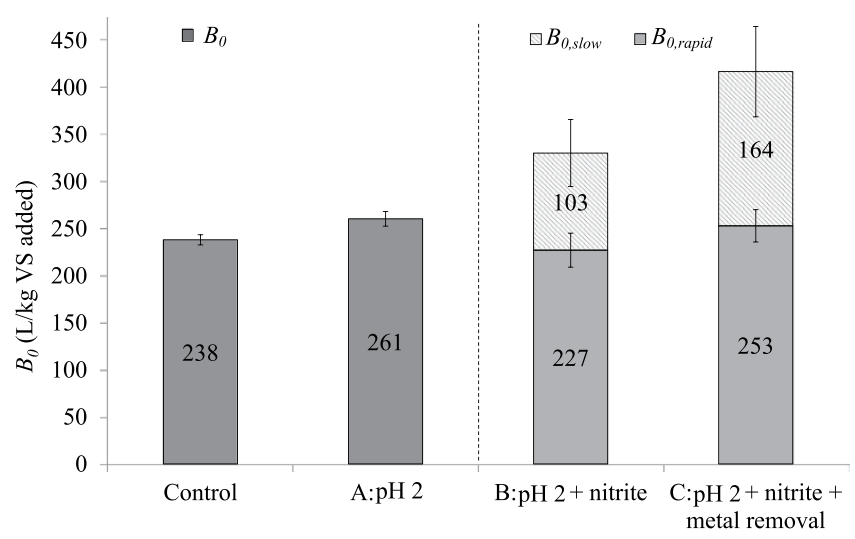

Figure 2. Estimated biochemical methane potential $\left(B_{0}\right)$ of WAS after different treatments. The $B_{0}$ of Control and treatment (A) were estimated using the one-substrate model. The $B_{0}$ of treatment $(\mathbf{C}, \mathbf{D})$ were estimated using the two-substrate model with $k_{\text {slow }}$. at their optima. The top error bars for treatment $(\mathbf{B}, \mathbf{C})$ represents the combined error $\left(95 \%\right.$ confidence interval) of $B_{0, \text { rapid }}+B_{0, \text { slow }}$.

$B_{0}$ of the control and treatment $A$. The increase of the final methane production mainly came from the addition of the slowly degradable substrates. In our previous study, nitrite addition to acidified sludge released organically bound metals in sludge ${ }^{16}$. Since FNA directly affects EPS by specifically targeting protein-like substances therby breaking down the macromolecules within the EPS matrix into smaller molecules ${ }^{17}$ and the fact that EPS is known to be relatively resistant to $\mathrm{AD}^{5}$, the disrupted EPS might be converted from non-digestible to (slowly) digestible. This is supported by the observed improvement of methane production in this study.

FNA has been reported for its ability to increase the biodegradability of sludge in both aerobic ${ }^{13}$ and anaerobic ${ }^{12}$ conditions, in which sludge treatment at 50-300 $\mathrm{mg} \mathrm{NO}_{2}^{-}-\mathrm{N} / \mathrm{L}$ and $\mathrm{pH} 5.5$ resulted in higher SCOD concentrations compared to $\mathrm{pH} 5.5$ treatment. It was speculated that the higher SCOD subsequently resulted in higher $k$ and $B_{0}$ values during the BMP test. However in this study, the treatment at $\mathrm{pH} 2$ with nitrite addition did not cause additional increase of SCOD of treated WAS or $k$ (or $k_{\text {rapid }}$ ), compared to $\mathrm{pH} 2$ only treatment. The increase in total methane production and $B_{0}$ revealed that nitrite addition at $\mathrm{pH} 2$ converted part of non-degradable substrates into slowly degradable substrates in the insoluble fraction of WAS. Hence, the results obtained in this study may indicate that the effectiveness of nitrite at $\mathrm{pH} 2$ is based on a different working mechanism than at $\mathrm{pH}$ 5.5. Further research is warranted to reveal the nature of the effect of nitrite on sludge at $\mathrm{pH} 2$.

Toxic metals are known for their inhibition effect on $\mathrm{AD}$ process, even when their concentration is lower than $10 \mathrm{mg} / \mathrm{L}^{21}$. The initial concentrations of $\mathrm{Cu}$ and $\mathrm{Zn}$ in this study were $10.9 \pm 0.6 \mathrm{mg} / \mathrm{L}$ and $16.1 \pm 0.9 \mathrm{mg} / \mathrm{L}$, respectively. Similar to our previous study ${ }^{16}$, the addition of nitrite substantially enhanced the toxic metal removal, achieving $43 \%$ and $70 \%$ for the removal efficiency of $\mathrm{Cu}$ and $\mathrm{Zn}$, respectively (see supplementary Table S1). By subsequent solid/liquid separation and precipitation, toxic metals were removed from the sludge in treatment $\mathrm{C}$, achieving $294 \pm 8 \mathrm{mg} / \mathrm{kg}$ dry solids and $207 \pm 8 \mathrm{mg} / \mathrm{kg}$ dry solids for $\mathrm{Cu}$ and $\mathrm{Zn}$ as the final concentrations, respectively. The enhanced removal of toxic metals significantly $(p<0.05)$ further increased cumulative methane production by $18 \%$ as presented in Fig. 1 . It was suspected that the partial release of inhibitory impact of $\mathrm{Cu}$ and $\mathrm{Zn}$ on the $\mathrm{AD}$ process was the reason for this increase of methane production.

Sludge dewaterability. Figure 3 shows that the treatment at $\mathrm{pH} 2$, either with or without nitrite addition, resulted in a significant increase $(p<0.05)$ in the solids content of the dewatered sludge cake. It can also be seen that the sludge dewaterability was not further improved by the nitrite addition, indicating that the enhanced dewaterability was caused by the acidic conditions. This is in agreement with Chen et al. ${ }^{22}$ who found that acidification of sludge to $\mathrm{pH} 2.5$ increased the solids content from about $18 \%$ to $24 \%$ through filtration dewatering. 


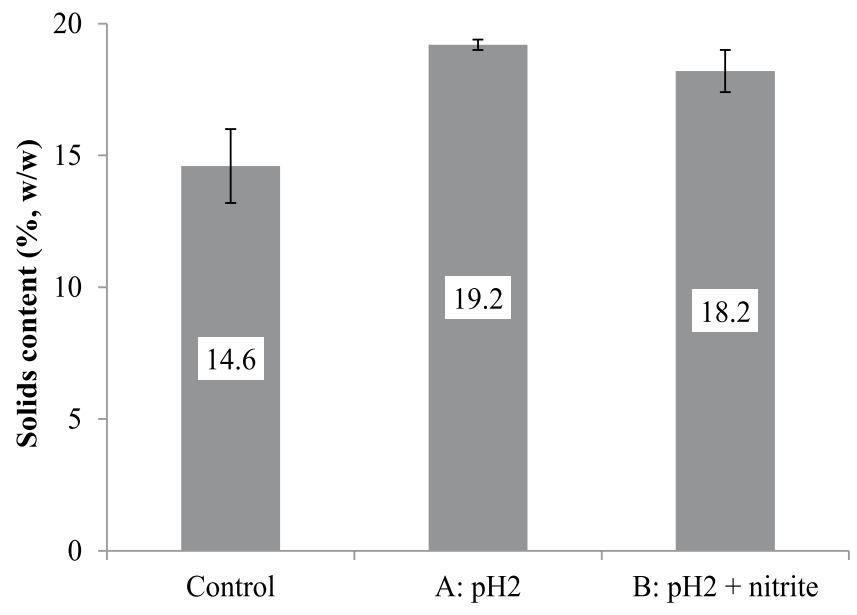

Figure 3. Solids content of belt filter dewatered sludge from different treatments.

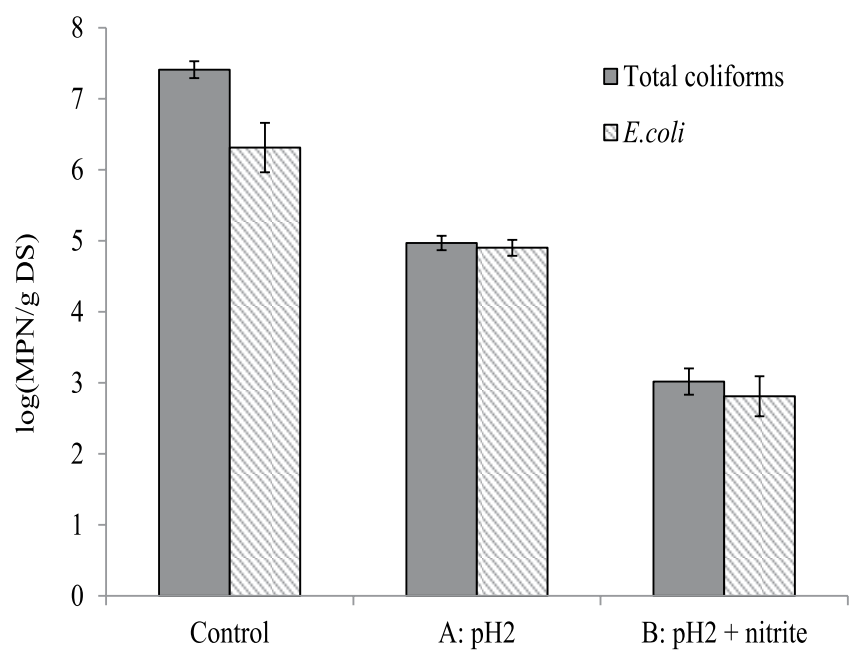

Figure 4. Concentration of total coliforms and E. coli in undigested sludge after different treatments.

As a result of the improved sludge dewaterability, the amount of wet sludge to be disposed would be reduced by about $20 \%$.

Pathogen reduction. Figure 4 shows the impact of acidification with and without nitrite addition on the pathogen reduction. It can be seen that the treatment at $\mathrm{pH} 2$ with nitrite addition resulted in a significantly $(p<0.05)$ higher reduction in pathogen indicators compared to acidification alone, achieving a 4 log reduction for both total coliforms and E. coli in terms of the most probable number (MPN) per gram of dry solids (DS), compared to a 3 and $2 \log$ units of concentration abatement for total coliforms and E. coli, respectively.

Regulation requires that WAS is stabilized to a specific level (E. coli $<100 \mathrm{MPN} / \mathrm{g}$ DS and Faecal coliforms $<1000 \mathrm{MPN} / \mathrm{g}$ DS) to achieve Grade A stabilisation for unrestricted land application ${ }^{10}$. In this study, the combination of $\mathrm{pH} 2$ and nitrite achieved a $4 \log$ unit reduction for MPN concentration of total coliforms and E. coli. In a study of Gantzer et al. ${ }^{23}$, it was found that mesophilic anaerobic digestion resulted in a $2 \log$ reduction in MPN. While this study cannot be directly compared with the results obtained here since sludge from a different origin was used, it does clearly show that FNA is an effective method for pathogen reduction. Equally important, the FNA based treatment employed in this study only required a HRT of $5 \mathrm{~h}$, much shorter than conventional mesophilic AD (commonly around 20 days $)^{5}$. However, the treatment by acidification with nitrite only achieved Grade A threshold for faecal coliforms while still one order of magnitude away from the threshold for E. coli. Further pathogen reduction may be achieved by increasing the nitrite dosing and HRT.

Implications for practice. Here, it was demonstrated that sludge acidification with the addition of only $10 \mathrm{mg} / \mathrm{L}$ of $\mathrm{NO}_{2}-\mathrm{N}$ simultaneously enhances sludge digestibility, toxic metal removal, dewaterability and pathogen reduction. Recently, the feasibility of on-site production of acid and caustic using a novel three compartment electrochemical cell was demonstrated ${ }^{24}$. In a practical situation, the increase in biogas production could be used to drive the electrochemical process and as such could potentially allow for the energy-neutral generation 
of acid and caustic. In addition, FNA could also be produced on-site directly from anaerobic digester liquor ${ }^{25}$. Combining these two recent findings could potentially allow for an energy-neutral sludge management strategy without the need for external chemical input.

\section{Methods}

Sludge source. Waste activated sludge (WAS) was collected from Luggage Point WWTP (Brisbane, Queensland, Australia). After collection, the sludge was immediately stored at $4{ }^{\circ} \mathrm{C}$, and all experiments were started within two weeks of sludge collection. The main sludge characteristics were: total solids (TS) $21.3 \pm 0.1 \mathrm{~g} / \mathrm{L}$; volatile solids (VS) $17.3 \pm 0.1 \mathrm{~g} / \mathrm{L}$; total chemical oxygen demand (TCOD) $28.0 \pm 0.1 \mathrm{~g} / \mathrm{L}$; soluble chemical oxygen demand (SCOD) $0.84 \pm 0.10 \mathrm{~g} / \mathrm{L}$, and $\mathrm{pH} 6.4 \pm 0.1$. The inoculum for the BMP tests was collected from the mesophilic anaerobic digester at the same WWTP treating a mixture of WAS and primary sludge. The TS and VS content of the inoculum sludge were $24.6 \pm 0.2 \mathrm{~g} / \mathrm{L}$ and $16.8 \pm 0.0 \mathrm{~g} / \mathrm{L}$, respectively. All sludge characteristics were analysed in triplicate.

Sludge treatment. To investigate the impact of acidification and nitrite treatment on the sludge digestibility, dewaterability and pathogen reduction, 3 different treatment conditions were investigated and compared with untreated sludge (control group). In treatment $\mathrm{A}$, WAS was acidified to $\mathrm{pH} 2$ for a period of 5 hours. In treatment $\mathrm{B}$ and $\mathrm{C}$, WAS was acidified to $\mathrm{pH} 2$ with the addition of $10 \mathrm{mg} \mathrm{NO}{ }^{-}-\mathrm{N} / \mathrm{L}$ for a period of 5 hours. In treatment $\mathrm{C}$, the acidification step was followed by a metal removal step. Metals were removed using the following procedure. Firstly, the WAS was centrifuged at $13,000 \times \mathrm{g}$ for $20 \mathrm{~min}$ (Centrifuge $5810 \mathrm{R}$, Eppendorf, Germany) to separate the solids and the WAS liquor. The WAS liquor was subsequently neutralized to $\mathrm{pH} 7$ to precipitate the metals. The precipitated metals were removed from the solution by filtration using Millipore filters $(0.22 \mu \mathrm{m}$ pore size, Millipore Express, USA). Subsequently, the filtrate and WAS solids were mixed (i.e. sludge minus metals removed).

In all experiments, the acidification and neutralisation was done by addition of $1 \mathrm{M} \mathrm{HCl}$ and $1 \mathrm{M} \mathrm{NaOH}$ respectively. A volume of $500 \mathrm{~mL}$ of WAS was used for each of the treatment conditions. All sludge treatment experiments were conducted in triplicate. For each triplicate, the treated sludge was subsequently used in 3 series of experiments to determine their impact on the sludge digestibility, dewaterability and pathogen reduction.

Biochemical Methane Potential (BMP). BMP tests were adopted to investigate the sludge digestibility as described by Jensen et al. ${ }^{26}$. For each BMP test, $50 \mathrm{~mL}$ of inoculum was used. Substrate (i.e. WAS from the control group and each treatment conditions) was added at an inoculum to substrate ratio of 2.0 on a VS basis. The volume of each BMP vial was topped up with Milli-Q water to $80 \mathrm{~mL}$. A blank was set up by mixing $50 \mathrm{~mL}$ of inoculum and $30 \mathrm{~mL}$ of Milli-Q water. After treatments A, B and C, the treated sludge was neutralized to its initial $\mathrm{pH}$ (i.e. $6.5 \pm 0.3$ ) before mixing with inoculum. To eliminate the possibility that results were affected by the shearing force during the centrifugation step in treatment $\mathrm{C}$, the samples from control as well as treatments $\mathrm{A}$ and $\mathrm{B}$ were also centrifuged and mixed under identical condition (but without removing the metals) prior to BMP tests.

After filling with inoculum and substrate, the vials were flushed with nitrogen gas for 30 seconds at a flow rate of $3.5 \mathrm{~L} / \mathrm{min}$ and then sealed with a butyl rubber stopper retained with an aluminum crimp-cap. An incubator maintaining $37 \pm 1{ }^{\circ} \mathrm{C}$ was used to store all the testing vials. The BMP tests were terminated after 70 days. The biogas $\left(\mathrm{CH}_{4}, \mathrm{H}_{2}\right.$ and $\left.\mathrm{CO}_{2}\right)$ production was measured every 1-2 days over the first 10 days and every 4-6 days afterwards. The biogas production from WAS was obtained by subtracting the average biogas production from the blank group (see supplementary Fig. S1). All tests were conducted in triplicates.

The apparent first order hydrolysis rate coefficient $(k)$ and biochemical methane potential $\left(B_{0}\right)$ were adopted as the key parameters for the assessment of WAS digestibility after different treatment. The values for them were estimated by fitting BMP data to a first-order kinetic model using a modified version of Aquasim 2.1d with sum of squared errors $\left(J_{o p t}\right)$ as an objective function, as described by Batstone et al. ${ }^{27}$ and Jensen et al. ${ }^{26}$. The uncertainty surfaces of $B_{0}$ and $k$ were estimated based on a model-validity $F$-test with $95 \%$ confidence limits. A one-substrate model and a two-substrate model ${ }^{12}$ were used. The one-substrate model is described in Eq. (1):

$$
B(t)=B_{0} \cdot\left(1-e^{-k \cdot t}\right)
$$

where $B(t)$ is cumulative methane yield at time $\mathrm{t}\left(\mathrm{L} \mathrm{CH}_{4} / \mathrm{kg} \mathrm{VS}\right.$ added); $B_{0}$ is the biochemical methane potential; $k$ is hydrolysis rate coefficient $\left(\mathrm{d}^{-1}\right) ; t$ is time $(\mathrm{d})$. In the two-substrate model, two types of substrates, i.e. rapidly degradable substrate and slowly degradable substrate, were considered, see Eq. (2):

$$
B(t)=B_{0, \text { rapid }} \cdot\left(1-e^{-k_{\text {rapid }} \cdot t}\right)+B_{0, \text { slow }} \cdot\left(1-e^{-k_{\text {slow }} \cdot t}\right)
$$

where $B(t)$ is cumulative methane yield at time $t$; $B_{0 \text {,rapid }}$ is the biochemical methane potential of rapidly degradable substrate; $k_{\text {rapid }}$ is hydrolysis rate coefficient of rapidly degradable substrate; $B_{0 \text {,slow }}$ is the biochemical methane potential of slowly degradable substrate; $k_{\text {slow }}$ is hydrolysis rate coefficient of slowly degradable substrate; $t$ is time. Total biochemical methane potential $B_{0}=B_{0 \text {,rapid }}+B_{0 \text {,slow }}$. Model fitness was evaluated by ANOVA by an $F$-test on non-linear regression sum of squared errors to assess whether Eq. (2) was significantly better.

To estimate the impact of the applied pre-treatment on methane production in a practical situation, i.e. continuous anaerobic digestion with a hydraulic retention time (HRT) of 20 days, a continuous reactor model was adopted with the $k$ and $B_{0}$ gained from the previous steps. A single substrate assumption was applied to predict the performance at an HRT of 20 days due to the relatively high uncertainty (and correlated parameter space) that existed with the two-substrate model. This is justified as the single substrate model provides a reasonable 
prediction of continuous performance specifically at a 20 day point. Numerical uncertainty propagation method described by Batstone ${ }^{28}$ was used to estimate the methane production, using the following equation:

One-substrate model:

$$
B(t)=B_{0} \times\left(1-\frac{1}{1+k t}\right)
$$

where $B(t)$ is cumulative methane yield at time $t\left(\mathrm{~L} \mathrm{CH}_{4} / \mathrm{kg} \mathrm{VS}\right.$ added $) ; B_{0}\left(B_{0, \text { rapid }}\right.$ and $\left.B_{0, \text { slow }}\right)$ is biochemical methane potential (for rapidly and slowly degradable substrate, respectively); $k\left(k_{\text {rapid }}\right.$ and $\left.k_{\text {slow }}\right)$ is hydrolysis rate coefficient (for rapidly and slowly degradable substrate, respectively) $\left(\mathrm{d}^{-1}\right) ; t$ is time $(\mathrm{d}) . t=20 \mathrm{~d}$ in this case. According to Batstone ${ }^{28}$, the calculation of $B(t)$ using Equation 3 was conducted by 10,000 simulations, applying observed distributions for the parameters. The average values of the $B(20)$ were adopted as the estimated practical methane production in a continuous anaerobic digester with $20 \mathrm{~d}$ HRT.

Through AD, the mass of sludge is reduced due to the degradation of VS into methane. It was assumed that the inorganic solids in WAS would not be digested. The VS destruction can be calculated in accordance with Eq. (4):

$$
\text { VS destruction } \%=\frac{B(t)}{380 \times 1.56} \times 100 \%
$$

where $B(t)$ is the biochemical methane production at time $t\left(\mathrm{~L} \mathrm{CH}_{4} / \mathrm{kg}\right.$ VS added); 380 is theoretical biochemical methane potential under standard conditions $\left(25^{\circ} \mathrm{C}, 1 \mathrm{~atm}\right)\left(\mathrm{L} \mathrm{CH}_{4} / \mathrm{kg}\right.$ TCOD $) ; 1.56$ is the TCOD/VS ratio of the WAS used in this study.

Dewaterability. The impact of treatments A and B on the dewaterability of the treated sludge was evaluated by the belt filter proxy test described by Higgins et al. ${ }^{29}$ without using any conditioning agent. The sludge dewaterability was determined and compared by measuring the dewatered sludge cake solids concentration (\% w/w).

Pathogen reduction. Total coliforms and E. coli were selected as indicators of pathogen in WAS ${ }^{10,30}$. The impact of the different sludge treatment methods on the pathogen reduction were analyzed using the Colilert $^{\circledR}-18$ kit test (IDEXX, U.S.A), according to Eccles et al. ${ }^{31}$. Prior to analysis, the WAS subject to treatments A and B was neutralized to their initial $\mathrm{pH}$ values of $6.5 \pm 0.3$.

Analytical methods. The TS and VS concentrations were determined using standard methods ${ }^{32}$. TCOD and SCOD were analysed using Spectroquant ${ }^{\circledR}$ COD cell tests (Merck, Germany). For analysis of the SCOD concentrations, samples were first filtered using a $0.22 \mu \mathrm{m}$ syringe filter (Milipore, USA). In all experiments, $\mathrm{pH}$ was measured using a handheld $\mathrm{pH}$ meter ( $\mathrm{pH}$ meter 11 series, Oakton, Australia). The analysis of toxic metal concentrations was conducted by inductively coupled plasma optical emission spectrometry (ICP-OES, 7300DV, PerkinElmer, USA) according to Du et al. ${ }^{16}$.

During the course of the BMP experiments, the gas phase pressure was measured by a monometer before each sampling event. The cumulative volume of the produced gas was calculated according to the pressure in the headspace $(80 \mathrm{~mL})$ and expressed under standard conditions $\left(25^{\circ} \mathrm{C}, 1 \mathrm{~atm}\right)$. The biogas composition $\left(\mathrm{CH}_{4}, \mathrm{CO}_{2}, \mathrm{H}_{2}\right)$ was analysed using a gas chromatograph (GC-2014, Shimadzu, Australia) equipped with a thermal conductivity detector and a HAYESEP Q 80/100 packed column, as described by Astals et al. ${ }^{33}$. Argon was used as a carrier gas with a flow rate of $28 \mathrm{~mL} / \mathrm{min}$ at $135.7 \mathrm{kPa}$. The temperature of the chromatograph injector was set at $348.15 \mathrm{~K}$, whereas the temperature of the oven and detector were set at $318.15 \mathrm{~K}$ and $373.15 \mathrm{~K}$, respectively.

To evaluate the impacts of the treatments, measures of average sludge characteristics after treatment were compared with the control group and each other, using 95\% confidence interval in mean based on a two-tailed $\mathrm{t}$-test in measure standard error, according to Batstone $(2013)^{28}$.

\section{References}

1. Bennamoun, L., Arlabosse, P. \& Léonard, A. Review on fundamental aspect of application of drying process to wastewater sludge. Renewable and Sustainable Energy Reviews 28, 29-43 (2013).

2. Grøn, C. Organic contaminants from sewage sludge applied to agricultural soils. False alarm regarding possible problems for food safety? Environ. Sci. Pollut. R. 14, 53-60 (2007)

3. Pérez-Elvira, S. I., Nieto Diez, P. \& Fdz-Polanco, F. Sludge minimisation technologies. Rev. Environ. Sci. Biotechnol. 5, 375-398 (2006).

4. Wang, J. et al. A modified oxic-settling-anaerobic activated sludge process using gravity thickening for excess sludge reduction. Scientific Reports 5, 13972 (2015).

5. Carrère, H. et al. Pretreatment methods to improve sludge anaerobic degradability: A review. J. Hazard. Mater. 183, 1-15 (2010).

6. Ge, H., Jensen, P. D. \& Batstone, D. J. Temperature phased anaerobic digestion increases apparent hydrolysis rate for waste activated sludge. Water Res. 45, 1597-1606 (2011).

7. Wang, Q. et al. Polyhydroxyalkanoates in waste activated sludge enhances anaerobic methane production through improving biochemical methane potential instead of hydrolysis rate. Scientific Reports 6, 19713 (2016).

8. Lu, Q., He, Z. L. \& Stoffella, P. J. Land application of biosolids in the USA: a review. Appl. Environ. Soil Sci. 2012, 201462 (2012).

9. Pritchard, D. L., Penney, N., McLaughlin, M. J., Rigby, H. \& Schwarz, K. Land application of sewage sludge (biosolids) in Australia: risks to the environment and food crops. Water Sci. Technol. 62, 48-57 (2010).

10. NSW-EPA. Environmental guidelines: use and disposal of biosolids products (2000).

11. He, C., Giannis, A. \& Wang, J.-Y. Conversion of sewage sludge to clean solid fuel using hydrothermal carbonization: Hydrochar fuel characteristics and combustion behavior. Applied Energy 111, 257-266 (2013).

12. Wang, Q. et al. Free nitrous acid (FNA)-based pretreatment enhances methane production from waste activated sludge. Environ. Sci. Technol. 47, 11897-11904 (2013).

13. Wang, Q. \& Yuan, Z. Enhancing aerobic digestion of full-scale waste activated sludge using free nitrous acid pre-treatment. RSC Advances 5, 19128-19134 (2015). 
14. Jiang, G., Gutierrez, O. \& Yuan, Z. The strong biocidal effect of free nitrous acid on anaerobic sewer biofilms. Water Res. 45, 3735-3743 (2011).

15. Sánchez-Monedero, M. A., Mondini, C., de Nobili, M., Leita, L. \& Roig, A. Land application of biosolids. Soil response to different stabilization degree of the treated organic matter. Waste Manag. 24, 325-332 (2004).

16. Du, F., Freguia, S., Yuan, Z., Keller, J. \& Pikaar, I. Enhancing Toxic Metal Removal from Acidified Sludge with Nitrite Addition. Environ. Sci. Technol. 49, 6257-6263 (2015).

17. Zhang, T., Wang, Q., Khan, J. \& Yuan, Z. Free nitrous acid breaks down extracellular polymeric substances in waste activated sludge. RSC Advances 5, 43312-43318 (2015).

18. Altaş, L. Inhibitory effect of heavy metals on methane-producing anaerobic granular sludge. J. Hazard. Mater. 162, 1551-1556 (2009).

19. Chen, Y., Cheng, J. J. \& Creamer, K. S. Inhibition of anaerobic digestion process: A review. Bioresour. Technol. 99, 4044-4064 (2008).

20. Zhou, X., Jiang, G., Wang, Q. \& Yuan, Z. A review on sludge conditioning by sludge pre-treatment with a focus on advanced oxidation. RSC Advances 4, 50644-50652 (2014).

21. Wong, M. H. \& Cheung, Y. H. Gas production and digestion efficiency of sewage sludge containing elevated toxic metals. Bioresour. Technol. 54, 261-268 (1995).

22. Chen, Y., Yang, H. \& Gu, G. Effect of acid and surfactant treatment on activated sludge dewatering and settling. Water Res. 35, 2615-2620 (2001).

23. Gantzer, C. et al. Monitoring of bacterial and parasitological contamination during various treatment of sludge. Water Res. 35, 3763-3770 (2001).

24. Lin, H.-W. et al. Direct anodic hydrochloric acid and cathodic caustic production during water electrolysis. Scientific Reports 6, 20494 (2016).

25. Law, Y. et al. Producing free nitrous acid-A green and renewable biocidal agent-From anaerobic digester liquor. Chem. Eng. J. 259, 62-69 (2015).

26. Jensen, P., Ge, H. \& Batstone, D. J. Assessing the role of biochemical methane potential tests in determining anaerobic degradability rate and extent. Water Sci. Technol. 64, 880-886 (2011).

27. Batstone, D. J., Tait, S. \& Starrenburg, D. Estimation of hydrolysis parameters in full-scale anerobic digesters. Biotechnol. Bioeng. 102, 1513-1520 (2009).

28. Batstone, D. J. Teaching uncertainty propagation as a core component in process engineering statistics. Education for Chemical Engineers 8, e132-e139 (2013).

29. Higgins, M., Schauer, P. \& Beightol, S. In WEF Residuals and Biosolids.

30. USEPA. Standards for the use or disposal of sewage sludge (2007).

31. Eccles, J. P., Searle, R., Holt, D. \& Dennis, P. J. A comparison of methods used to enumerate Escherichia coli in conventionally treated sewage sludge. J. Appl. Microbiol. 96, 375-383 (2004).

32. American Public Health Association (APHA), the American Water Works Association (AWWA), and the Water Environment Federation (WEF) Standard methods for the examination of water and wastewater. 20th edn, Vol. 1268 (American Public Health Association, 1998).

33. Astals, S. et al. Anaerobic co-digestion of pig manure and algae: Impact of intracellular algal products recovery on co-digestion performance. Bioresour. Technol. 181, 97-104 (2015).

\section{Acknowledgements}

This work was funded by the Australian Research Council Discovery Project DP120104415 and Australian Research Council Linkage Project LP130100361. The authors would like to acknowledge Dr. Beatrice KellerLehmann, Mr Nathan Clayton and Ms Jianguang Li for their help with the chemical analysis. The authors would like to acknowledge Dr. Paul Jensen, Dr. Huoqing Ge and Dr. Qilin Wang for their help on BMP tests. Fangzhou Du would like to acknowledge the scholarship support from China Scholarship Council and Tuition Fee Scholarship from The University of Queensland.

\section{Author Contributions}

F.D., J.K. and I.P. conceived and designed the research. F.D. conducted the experiment, analysed, interpreted the data, and wrote the manuscript. D.B reviewed the modelling and statistical analysis parts. All authors analysed the data and reviewed the manuscript.

\section{Additional Information}

Supplementary information accompanies this paper at http://www.nature.com/srep

Competing financial interests: The authors declare no competing financial interests.

How to cite this article: Du, F. et al. Nitrite addition to acidified sludge significantly improves digestibility, toxic metal removal, dewaterability and pathogen reduction. Sci. Rep. 6, 39795; doi: 10.1038/srep39795 (2016).

Publisher's note: Springer Nature remains neutral with regard to jurisdictional claims in published maps and institutional affiliations.

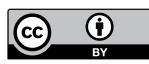

This work is licensed under a Creative Commons Attribution 4.0 International License. The images or other third party material in this article are included in the article's Creative Commons license, unless indicated otherwise in the credit line; if the material is not included under the Creative Commons license, users will need to obtain permission from the license holder to reproduce the material. To view a copy of this license, visit http://creativecommons.org/licenses/by/4.0/

(c) The Author(s) 2016 